\title{
The Students' Attitude toward English Instruction on the EFL Students' Speaking Class
}

\author{
Nirma Paris ${ }^{1}$ Rafiqa $^{1}$ \\ ${ }^{1}$ Universitas Sulawesi Barat, Majene, Indonesia \\ Email: nirma.paris@gmail.com
}

\begin{abstract}
In general, an English teacher uses bilingual method in teaching process. However, a native English teacher uses English only in the class. Due to the new atmosphere faced by the students, the present study aimed to investigate the students' attitude toward English instruction on the EFL students' speaking class. This current study employed a quantitative method and it was designed as a descriptive research. The participants of this study were 156 students of English Study Program enrolled at Speaking class, Faculty of Tarbiyah, State Islamic Institute of Parepare. A 20-item survey questionnaire related to the students' attitude toward English instruction with a five point likert scale was assigned to obtain the data from the participants. The results of the study revealed that the students have a positive attitude toward English instruction. They agreed with teaching English by using English instruction. The students' cognitive and affective responses showed that the students believed that English instruction could improve the students' abilities at intermediate level. Furthermore, the students' cognitive responses indicated that the students' vocabularies and grammatical knowledge improved. The use of English instruction also gave the students an opportunity to learn pronunciation from the native English teacher. While, the results of affective responses indicated that the students liked to study using English instruction and they were motivated to speak in English.
\end{abstract}

Keywords: EFL students, English instruction, native English teacher, speaking, students' attitude,

\section{INTRODUCTION}

Language is means of human communication. It is used not only to express thought, emotion, feeling, and opinion but it is also used to interact with other people in society. Thomas (1987) proposed that interaction means acting equally, acting upon each other. In Indonesia, most of English Foreign Language (EFL) students communicate using bilingual method, especially English and Bahasa. Lado (1988) stated that in bilingual method the students must learn both languages and it assumes that the students already speak one of the two languages and be able to use both of them to learn other subjects as well as to communicate through them.

Based on the previous observation, the application of bilingual method in English Study Program of Islamic State Institute of Parepare commonly uses concurrent approach. Mejia (2002) stated that concurrent approach is an approach where two languages, in this case English and Bahasa, are used concurrently by a means of classroom code- 
switching teachers and learners. In teaching process, the teachers recognize that some of students do not understand if they speak whole in English. On the other hand, the students do not have much available time to open a dictionary and translate all the words. Therefore, the teachers translate what they said to help their students clearly understand. In this case, mother language helps the students. This condition was in line with a study of Kim and Petraki (2009) which revealed that mother language plays a supportive role in the language classroom, especially at the basic level.

However, a new atmosphere is faced by the students as there is a native English teacher from The United State of America who teaches in Islamic State Institute of Parepare. In the teaching process, she uses English only. Specially, she teaches English through English. This means that she speaks and uses English in the classroom as often as possible. To further explain, she uses English only when she is organizing the class and teaching the students. In other words, it means that she is establishing English as the main language between the students and the teacher, and that English must be practiced during the learning process (Willis, 1987).

In learning process, it is necessary for teacher and students to communicate. In this case, Harmer (1991) stated that communication among humans requires speaker and listener. There are some reasons when the people intend to talk each other. This nature of communication is divided into the nature of speaking and the nature of listener. The nature of speaking consists of the speaker's willingness to say something, the purpose of communication, and the selection of language use. While, the nature of listener consists of the listener's willingness to listen something, the interest in communication purpose, and the ability to process a variety of language.

In line with the previous view mentioned, Clark (1977) postulated that speaking is fundamentally an instrumental act as the speakers talk in order to have some effect on their listener. To further explained, speaking is viewed as a tool to express someone's feeling, emotion, and opinion. As someone speaks, he expects feedback from a listener. In addition, Bahar (2007) stated that speaking is to say something from one's feeling and mind which is expressed by a sequence of sounds, words, and sentences. It is seen that pronunciation, vocabulary, and fluency have a main role in the skill of speaking. In teaching spoken language, Brown (2001) proposed that there are some components of teaching spoken language such as conversational discourse, pronunciation, accuracy and fluency, affective factors, and the interaction effect. This paper assumes that the students may have different attitude if teaching spoken English uses bilingual method and English only.

According to Webster's Dictionary (2003), attitude is a state of mind, behavior, or action concerning some problem as indication of belief or purpose. It is seen as the appropriate position to express some feeling, either consciously or unconsciously assumed. In addition, Hornby (2000) stated that attitude is the way that people think and feel about something. To explain, it is the way that people behave towards something that shows how they think and feel. Based on the definition mentioned above, this paper defines attitude as an 
expression of someone's thoughts, emotions, and feelings that can be seen by looking at how someone behaves and acts.

Sudjana (2008) proposed that there are three components of attitude such as cognitive response, affective response, and behavioral response. Cognitive response refers to thoughts, beliefs, and ideas toward certain object or stimulus. Move to affective response, it refers to feelings or emotions of an individual toward an object. This kind of attitude appears in some students behavior such as their attention toward a subject, discipline, respect toward the teacher or their friend, and social interaction. While, behavioral response refers to the behavior tendency or disposition of an individual toward a certain object. It also refers to the skill or action that comes after receiving an experience. These components of attitude are related each other.

In accordance with learning attitude, Djaali (2009) claimed that learning attitude has an essential role in determining students' activity. It decides the intensity of the learning activity. Positive learning attitude causes higher intensity in the activity than negative learning attitude. To measure the students' attitude, an attitude scale is a common way that is used and it has been employed in numerous studies. Sudjana (2008) proposed that an attitude scale is used to measure an individuals' attitude toward a certain object. In addition, Oppenheim (1976) also claimed that attitude scale functions to divide people roughly into a number of broad groups, with regard to a particular attitude. This technique attempts to categorize what an individual believes, perceives, or feels (Gay, 1996). Furtheremore, Oppenheim (1976) mentions several technique in measuring attitude such as likert scale, thursone scale, and guttman scale.

There are a number of studies related to attitude toward English instruction. Léger and Storch (2009) conducted a study on learners' perceptions and attitudes for communication in an L2 classroom. Thirty-two students of French (L2) participated in this study. The result revealed that the students' perception of the speaking activities as learners in the foreign language classroom affected their willingness to communicate in a range of ways.

Another study related to attitude was conducted by Kim and Petraki (2009). This study investigated the attitudes of students and teachers' attitude to the use of L1 in EFL classrooms in multilevel language classrooms (beginner, intermediate, and advance students). The result revealed that that $\mathrm{L} 1$ plays a supportive role in the language classroom in the early stage, less in intermediate and even less in the advance levels. In addition, Korean students agreed with Korean teachers about the usefulness of L1 while native speaker English language teachers emphasized the importance of using L1 exclusively. To further explain, the mother tongue was found useful for explaining the meaning of words and grammatical explanations. However, giving instructions for pair work and group work activities do not require the use of students' mother tongue.

There was also a study conducted by Vizconde (2006). The study investigated attitudes of student teachers towards the use of English as language of instruction. Nineteen (19) pre-service teachers in the Philippines participated in this study. The result found that the student teachers have positive attitude 
toward English. It suggested that English is necessary language in teaching. In addition, both languages be allowed as media of instruction for teaching the content subject. The majority of the student teachers preferred the alternating use of both Filipino and English inside their classroom. English should be the only medium in their classroom.

The previous studies mentioned proves that the students have positive attitude toward English instruction for EFL students. However there are only limited study regarding the students' attitude toward English instruction in Indonesia. In addition, the Indonesian EFL university students at Islamic State Institute of Parepare faced new atmosphere as the native English teacher use English only in teaching. Therefore, the current study attempted to examine the students' attitude toward English instruction on the EFL students' class. In particular, it aimed to investigate Indonesian university students at intermediate level enrolled at Speaking class that taught by native English teacher.

\section{METHODODOLOGY}

The present study aimed to investigate the students' attitude toward English instruction on the EFL students' speaking class. This study employed a quantitative method and it was designed as a descriptive research. The participants of this study were 156 sophomore students of English Study Program, Faculty of Tarbiyah, State Islamic Institute of Parepare (IAIN Parepare). The participants were chosen as they were taught by a native English teacher and enrolled in speaking class. Their average English proficiency was intermediate level according to the university test; meanwhile their mother tongue varies from Buginese, Mandarnese, Pattinjonese, Makkasarnese, to Bahasa. They graduated from state senior high school, Islamic senior high school, and vocational high school. They formally started learning English since their junior high school education and some even earlier as their elementary school education.

The instrument used in this study was a survey questionnaire. It was used to obtain information about the students' attitude toward English instruction on the EFL students' speaking class. The questionnaire consisted of 20 statements. The statements were divided into two (2) sections. The first section was statement 1 to statement 10 . The purpose of this section was to obtain information regarding the students' cognitive response toward English instruction. The second section was statement 11 to statement 20 . The purpose of this section was to know the students' affective response toward English instruction. The questionnaire was given on the form of a five-point likert scale with 10 positive and 10 negative statements, positive statement at odd number and negative statement at even number. The questionnaire was given in Bahasa to ensure efficiency in communication and it has been checked by expert.

To conduct the current study, the researchers contacted the potential participants and made an appointment in order to fill out the questionnaire. This data collected at Faculty of Tarbiyah, State Islamic Institute of Parepare (IAIN Parepare). To analyze the data, the questionnaire was evaluated based on a five-point likert scale. On the positive 
statement, it was scored 5 for strongly agree, 4 for agree, 3 for undecided, 2 for disagree, and 1 for strongly disagree. Meanwhile, on the negative statement, it was scored 1 for strongly agree, 2 for agree, 3 for undecided, 4 for disagree, and 1 for strongly disagree. Then, the students' score of each statement were calculated. After that, to get the percentage of the students' score, sum of scores divided by the highest score (number of students multiplied by five), and then multiplied by 100 (sum of scores/the highest score x 100). Finally, the students' attitude were categorized and classified as follow:

$\begin{array}{ll}\text { Very strong } & : 81 \%-100 \% \\ \text { Strong } & : 61 \%-80 \% \\ \text { Enough } & : 41 \%-60 \% \\ \text { Low } & : 21 \%-40 \%\end{array}$

Very low $\quad: 0 \%-20 \%$

\section{FINDING AND DISCUSSION}

Based on the data collected from the questionnaires, the researchers present the finding and discussion to gain information regarding the students' attitude toward English instruction on the EFL students' speaking class. The research was conducted at State Islamic Institute of Parepare (IAIN Parepare), especially for sophomore students of English Study Program enrolled in speaking class and taught by native English teacher.

\section{Cognitive Responses}

Table 1 shows the students' cognitive response toward English instruction on the EFL students' speaking class.

Table 1. The students' cognitive response toward English instruction

\begin{tabular}{|c|c|c|c|c|c|c|}
\hline & Statement & Score & $\begin{array}{l}\text { Likert } \\
\text { Scale }\end{array}$ & $\%$ & Level & Rank \\
\hline Item 1 & My vocabularies are increased by using English instruction. & 540 & Agree & $69.23 \%$ & Strong & 2 \\
\hline Item 2 & $\begin{array}{l}\text { The use of English instruction does not increase my } \\
\text { grammar. }\end{array}$ & 501 & Disagree & $64,23 \%$ & Strong & 5 \\
\hline Item 3 & $\begin{array}{l}\text { I can explain the native English teacher's explanation by } \\
\text { using my own word. }\end{array}$ & 488 & Agree & $62.56 \%$ & Strong & 7 \\
\hline Item 4 & $\begin{array}{l}\text { I am difficult to understand the lesson using English } \\
\text { instruction. }\end{array}$ & 441 & Undecided & $56,54 \%$ & Enough & 10 \\
\hline Item 5 & $\begin{array}{l}\text { I can practice the pronunciation of the native English } \\
\text { teacher. }\end{array}$ & 540 & Agree & $69.23 \%$ & Strong & 3 \\
\hline Item 6 & I cannot practice the style of native English teacher. & 444 & Undecided & $56,92 \%$ & Enough & 9 \\
\hline Item 7 & I use diction in speaking. & 495 & Agree & $63.46 \%$ & Strong & 6 \\
\hline Item 8 & I do not use grammar in speaking. & 479 & Disagree & $61.41 \%$ & Strong & 8 \\
\hline Item 9 & $\begin{array}{l}\text { I can relate material taught with the previous one at the } \\
\text { native English teacher's class. }\end{array}$ & 509 & Agree & $65.26 \%$ & Strong & 4 \\
\hline Item 10 & $\begin{array}{l}\text { My English ability does not increase by using English } \\
\text { instruction by the teacher. }\end{array}$ & 563 & Disagree & $72.18 \%$ & Strong & 1 \\
\hline
\end{tabular}


It can be seen in table. 1 that there were ten (10) statements on the cognitive response, item 1 to item 10. It demonstrated that the highest rank of the students' cognitive response was item 10 . The students stated that they disagreed if their English ability did not increase by using English instruction by the teacher. In another word, the students' English ability increased by using English instruction only by the teacher with the percentage of $72.18 \%$. This statement was categorized in a strong level. The second rank of the students' attitude was that the students' vocabularies increased by using English instruction (item 1) with the percentage of $69.23 \%$. The students agreed with this statement and it was categorized in a strong level. The third rank of the students' attitude was that the students could practice the pronunciation of the native English teacher (item 5) with the percentage of $69.23 \%$. The students agreed with this statement and it was categorized in a strong level. The fourth rank of the students' attitude was that the students could relate material taught with the previous one at the native English teacher's class (item 9) with the percentage of $65.26 \%$. The students agreed with this statement and it was categorized in a strong level. The fifth rank of the students' attitude was that the students disagreed if the use of English instruction did not increase their grammar (item 2) with the percentage of $64.23 \%$. In another word, the use English instruction increased the students' grammar. This statement was categorized in a strong level. The sixth rank of the students' attitude was that the students used diction in speaking (item 7) with the percentage of $63.46 \%$. The students agreed with this statement and it was categorized in a strong level. The seventh rank of the students' attitude was the students could explain the native English teacher's explanation by using their own word (item 3) with the percentage of $62.56 \%$. The students agreed with this statement and it was categorized in a strong level. The eighth rank of the students' attitude was that the students disagreed if they did not use grammar in speaking (item 8) with the percentage of $61.41 \%$. In another word, the students used grammar in speaking. This statement was categorized in a strong level. The ninth rank of the students' attitude was that the students could not practice the style of native English teacher (item 6) with the percentage of $56.92 \%$. This statement was undecided attitude and it was categorized in an enough level. The tenth rank of the students' attitude was that the students were difficult to understand the lesson using English instruction (item 4) with the percentage of $56.54 \%$. This statement was undecided attitude and it was categorized in an enough level.

The findings showed that eight out of ten statements indicates that the students agreed with teaching by using English instruction. The students' cognitive response indicated that the students' English ability increased due to English instruction. Furthermore, the students' vocabularies and grammar knowledge improved. The data also represented that the students could learn the pronunciation from the native English teacher and use diction in speaking. The use of English instruction also trained the students' ability to re-explain material using their own language and the students could relate the previous subject matter.

In terms of the students' vocabularies and grammatical knowledge, the students strongly 
believed that their abilities improved. This phenomenon demonstrated that the students became aware that they could increase their abilities as they got English instruction. Regarding pronunciation and diction, the students strongly believed that having English instruction could improve their competences. Underlying the ability to use their own language and the background knowledge, the students strongly assured that their capability also improved.

In summary, it could be strongly stated that the students' cognitive response toward English instruction on Indonesian EFL university students had a positive attitude. Many students believed that having English instruction helped them to increase their vocabularies and grammatical knowledge. Besides, the students believed that having English instruction gave them an opportunity to learn and practice more pronunciation and use diction from the native English teacher. Finally they believed that their ability to use their own language in speaking improved.

\section{Affective Responses}

Table 2 shows the students' affective response toward English instruction on the EFL students' speaking class.

Table 2. The students' affective response toward English instruction

\begin{tabular}{|c|c|c|c|c|c|c|}
\hline & Statement & Score & $\begin{array}{l}\text { Likert } \\
\text { Scale }\end{array}$ & $\%$ & Level & Rank \\
\hline Item 11 & I like studying at the native English teacher's class. & 656 & Strongly Agree & $84.10 \%$ & Very strong & 1 \\
\hline Item 12 & I feel bored at the native English teacher's class. & 621 & Disagree & $79.62 \%$ & Strong & 4 \\
\hline Item 13 & I interact by using English at the native English teacher's class. & 536 & Agree & $68.27 \%$ & Strong & 6 \\
\hline Item 14 & $\begin{array}{l}\text { I do not ask the native English teacher about a material that I } \\
\text { do not understand at the class. }\end{array}$ & 480 & Disagree & $61.54 \%$ & Strong & 9 \\
\hline Item 15 & $\begin{array}{l}\text { The use of English instruction motivates me to learn the next } \\
\text { material. }\end{array}$ & 630 & Strongly agree & $81 \%$ & Very strong & 3 \\
\hline Item 16 & $\begin{array}{l}\text { I do not pay attention the explanation of the native English } \\
\text { teacher. }\end{array}$ & 631 & $\begin{array}{l}\text { Strongly } \\
\text { disagree }\end{array}$ & $81 \%$ & Very strong & 2 \\
\hline Item 17 & $\begin{array}{l}\text { I can apply material that I got at the native English teacher's } \\
\text { class into another class. }\end{array}$ & 524 & Agree & $67.18 \%$ & Strong & 8 \\
\hline Item 18 & $\begin{array}{l}\text { I am difficult to express my opinion at the native English } \\
\text { teacher's class. }\end{array}$ & 438 & Undecided & $56.15 \%$ & Enough & 10 \\
\hline Item 19 & I speak English out of campus with my friends. & 536 & Agree & $68.72 \%$ & Strong & 5 \\
\hline Item 20 & I rarely ask my friends to speak in English at daily activity. & 526 & Disagree & $67.44 \%$ & Strong & 7 \\
\hline
\end{tabular}


It can be seen in table. 2 that there were ten (10) statements on the affective response, item 11 to item 20. It demonstrated that the highest rank of the students' affective response was item 11 . The students stated that they liked studying at the native English teacher's class (item 11) with the percentage of $84.10 \%$. The students strongly agreed with this statement and it was categorized in a very strong level. The second rank of the students' attitude was that the students strongly disagreed if they did not pay attention to the explanation of the native English teacher (item 16). In another word, the students pay attention to the explanation of the native English teacher with the percentage of $81 \%$. This statement was categorized in a very strong level. The third rank of the students' attitude was that the use of English instruction motivated the students to learn the next material (item 15) with the percentage of $81 \%$. The students strongly agreed with this statement and it was categorized in a very strong level. The fourth rank of the students' attitude was the students disagreed if they felt bored at the native English teacher's class (item 12) with the percentage of $79.62 \%$. In another word, the students felt happy at the native English teacher's class. The students was categorized in a strong level. The fifth rank of the students' attitude was that the students spoke English out of campus with their friends (item 19) with the percentage of $68.72 \%$. The students agreed with this statement and it was categorized in a strong level. The sixth rank of the students' attitude was that the students were interacted by using English at the native English teacher's class (item 13) with the percentage of $68.27 \%$. The students agreed with this statement and it was categorized in a strong level. The seventh rank of the students' attitude was that the students disagreed if they rarely asked their friends to speak in English at daily activity (item 20) with the percentage of $67.44 \%$. In another word, the students often asked their friends to speak in English at daily activity. The students was categorized in a strong level. The eighth rank of the students' attitude was that the students could apply material that they got at the native English teacher's class into another class (item 17) with the percentage of $67.18 \%$. The students agreed with this statement and it was categorized in a strong level. The ninth rank of the students' attitude was that the students disagreed if they did not ask the native English teacher about a material that they did not understand at the class (item 14) with the percentage of 61.54\%. In another word, the students asked the native English teacher about a material that they did not understand at the class. The students was categorized in a strong level. The tenth rank of the students' attitude was that the students were difficult to express their opinion at the native English teacher's class (item 18) with the percentage of $56.15 \%$. This statement was undecided attitude and it was categorized in an enough level.

The findings showed that three out of ten statements of the students' affective response indicated that the students strongly agreed with teaching by using English instruction. In addition, the other six statements showed that the students have a positive attitude toward English instruction with agree statement. Therefore, the students' affective response indicated that the students like studying using English instruction by native English teacher. To further explain, the students enjoyed studying in the class and paid attention to the material explained 
by the native English teacher. In term of motivation, the students were motivated to speak English both in class and out of class. The students strongly believed that their motivation improved. This phenomenon demonstrated that the students became aware that their motivation increased due to the use of English instruction by the teacher.

In summary, it could be strongly stated that the students' affective response toward English instruction on Indonesian EFL university students had a positive attitude. Many students liked and enjoyed teaching using English instruction. Besides, the students also believed that having English instruction motivated them to speak in English.

\section{CONCLUSION}

It could be concluded from data analysis that the students have a positive attitude toward English instruction on the Indonesian EFL University students' speaking class. Regarding cognitive response, the students believed that English instruction could help them to improve their vocabularies and grammatical knowledge. They also believed that English instruction gave them an opportunity to learn and practice more their pronunciation. In term of affective response, the data showed that the students liked and enjoyed the English instruction class by the native English teacher. The students believed that using English instruction motivated them to speak in English. Overall, it could be further stated that English instruction is an affective for Indonesian EFL university students for intermediate level not only to improve their abilities especially in speaking, but also to motivate them to learn.

\section{REFERENCES}

Bahar, A.K. (2007). Let's Speak English Actively a Comprehensive Guiding Book for Speaking. Parepare: STAIN Parepare.

Brown, D. (2001). Teaching by Principles an Interactive Approach to Language Pedagogy. New York: Longman.

Clark, H. H. (1977). Psychology and Language an Introduction to Psycholinguistics. United State of America: Harcourt Brace Jovanovich.

Djaali (2009). Psikologi Pendidikan. Jakarta: Bumi Aksara.

Gay, L.R. (1996). Educational Research Competencies for Analysis and Application. Ohio, Florida: International University.

Harmer, J (1991). The Practice of English Language Teaching. Singapore: Longman.

Hornby, A.S. (2000). Oxford Advanced Learner's Dictionary. Oxford University Press.

Kim, Y., \& Petraki, E. (2009). Students' and teachers' use of and attitudes to L1 in the EFL Classroom. Asian EFL Journal, 11 (4), 58-89.

Lado, R. (1988). Teaching English across Cultures. Singapore: McGraw-Hill.

Léger, D., \& Storch, N. 2009. Learners' perceptions and attitudes: Implications for willingness to communicate in L2 classroom. System, 269-285.

Mejia, A. M. D. (2002). Power, Prestige and Bilingualism International Perspective on Elite Bilingual Education. Great Britain: Multilingual Matters Ltd.

Oppenheim, A. N. (1976). Questionnaire Designed and Attitude Measurement. Great Britain: Heinemann.

Sudjana, N. (2008). Penilaian Hasil Proses Belajar Mengajar. Bandug: PT Remaja Rosdakarya. The New International Webster's

Comprehensive Dictionary of the English Language. (2003). Columbia: Trindent Press International. 
Thomas, A. M. (1987). Classroom Interaction. Berlin: Oxford University Press.

Vizconde, C. (2006). Attitudes of student seachers towards the use of English as language of instruction for science and mathematics in the Philippines. The Linguistic Journal, 1 (3), 7-33.

Willis, J. (1987). Teaching English through English. Hong Kong: Longman 